\title{
The Effect Of Chief Executive Officers Turnover On International Financial Reporting Standards Reconciliation
}

Eun Sil Choi, Korea University, South Korea

Chang Seop Rhee, Sejong University, South Korea

\begin{abstract}
We investigate the impact of Chief Executive Officer (CEO) changes on International Financial Reporting Standards (IFRS) reconciliation. Since January $1^{\text {st }}, 2011$ all Korean listed companies are required to adopt IFRS in their separate and consolidated accounts. To aid investors in evaluating corporate performance over time, the companies must restate the K-GAAP financial statements for 2010 under IFRS. We find that negative IFRS reconciliation is more frequent for firms with CEO turnover in 2011. The result suggests that new CEOs have an incentive to report lower earnings through IFRS reconciliation for the purpose of big bath. Additionally, in order to examine whether new CEOs' incentive of the negative IFRS reconciliation is existed in different corporate governance levels, we classify the companies into strong and weak corporate governance. From the test, we find that their incentive of negative IFRS reconciliation is disappeared (existed) in the companies with strong (weak) corporate governance.
\end{abstract}

This study will contribute to academics and disclosure-related practitioners by providing valuable information of the CEO incentive regarding IFRS reconciliation. We believe that our empirical evidence will be helpful to market participants when they make a business decisions in case of CEO turnover.

Keywords: IFRS Reconciliation; CEO Turnover; Corporate Governance

\section{INTRODUCTION}

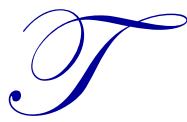

his paper investigates the influence of newly appointed Chief Executive Officer (CEO) on International financial Reporting Standards (IFRS) reconciliation at the time of IFRS adoption. Specifically, we measure the adjusted amounts from IFRS reconciliation and then make a group of the companies performing negative IFRS reconciliation using the adjusted amounts for testing the association between CEO turnover and the negative IFRS reconciliation. ${ }^{1}$ Since January 1st, 2011 Korean financial authority has required all Korean listed companies to adopt IFRS mandatorily. When the companies adopt IFRS, to aid investors in evaluating corporate performance over the periods, they need to restate the K-GAAP financial statements for 2010 under IFRS. Therefore, there are both IFRS financial information and K-GAAP financial information prepared for the financial statements for 2010, and then we can figure out the difference between IFRS earnings and K-GAA earnings.

IFRS reconciliation, the converting process from local GAAP financial statements to IFRS financial statement, is able to make a significant influence on future earnings after IFRS adoption. For instance, if newly appointed CEO in 2011 recognizes a great amount of plant asset impairment losses in the IFRS income statement for 2010 in advance using IFRS reconciliation, the reported earnings in 2010 will be reduced but the future earnings

\footnotetext{
${ }^{1}$ In this study, negative IFRS reconciliation (earnings under IFRS < earnings under local GAAP) indicates that earnings after IFRS reconciliation are less than earnings under local GAAP (Capkun et al., 2011). 
after 2011 will be increased. In short, new CEOs, appointed at the time of IFRS adoption, can have a power to generate smoother earnings reports for their overall CEO terms by deferring earnings for 2010 or pre-recognizing expenses for 2010 using IFRS reconciliation. Therefore, we believe that new CEOs have an incentive to use IFRS reconciliation for improving their future firm's performance.

European studies report that managers use IFRS reconciliation to improve their compensation (Capkun et al. 2011; Voulgaris et al. 2011). The studies about the association new CEOs' incentive and IFRS reconciliation is rarely covered at this time, but we predict that CEO change can have a strong influence on IFRS reconciliation following reasons. First, IFRS reconciliation affects future earnings after IFRS adoption. Garcia-Osma and Pope (2011) argue that as the firms reduce the amount of assets abnormally from IFRS reconciliation, their earnings quality are deteriorated after IFRS adoption. Capkun et al. (2011) also report that the companies, which report reduced earnings through IFRS reconciliation, are more likely to achieve their earnings targets after IFRS adoption. In other words, managers can use IFRS reconciliation for managing firms' earnings. Next, newly appointed CEOs in 2011 of Korean firms have an authority to determine the amounts of re-prepared financial statements for 2010 under IFRS. Especially, the purpose of re-prepared IFRS financial statements for 2010 is to compare with the financial information for 2011, and therefore the re-prepared IFRS financial statements for 2010 do not need to be audited by external auditors. In this circumstance, managers are more likely to abuse IFRS reconciliation for maximize their self-interests under no audit requirements.

We provide two pieces of multivariate logit analysis using 684 listed firm observations in Korea. First, we find that there is a significantly positive association between CEO turnover and negative IFRS reconciliation. The positive association is consistent with the view that new CEOs, at the IFRS adoption year, have an incentive to reduce earnings of prior year using IFRS reconciliation. Furthermore, in order to examine whether new CEOs' opportunistic behavior of negative IFRS reconciliation is existed in different corporate governance levels, we classify the companies with strong and weak corporate governance. From the empirical test, we find that the managers' incentive of negative IFRS reconciliation is disappeared (existed) in the companies with strong (weak) corporate governance. This result suggests that the strong corporate governance helps to control the new CEOs' opportunistic behavior of big bath using IFRS reconciliation.

This study contributes to the literature in the following ways. First, to our knowledge, there is no previous evidence on the direct positive association between new CEO appointment and IFRS reconciliation in Korea. We believe that the empirical evidences may shed a light on our understanding of managers' incentives from IFRS reconciliation. Second, this study provides insight into the importance of corporate governance on the relation between new CEO appointment and IFRS reconciliation. Also, this study may be helpful to market participants when they make a business decisions in case of CEO turnover.

The rest of this paper is organized as follow. Section 2 discusses the prior researches and develops our reasoning. Section 3 provides the research design and sample selection criteria. Section 4 reports the empirical results from the model estimation. Section 5 concludes the paper.

\section{BACKGROUND AND HYPOTHESES DEVELOPMENT}

\section{CEO Turnover}

Many accounting researches about CEO turnover focus on opportunistic behavior of new or former CEOs (Moore, 1973; Strong and Meyer, 1987; Murphy and Zimmerman, 1993; Pourciau, 1993; Rhee and Moon, 2005). Moore (1973) compares the proportion of income-decreasing discretionary accounting decisions from companies with management replacement and from companies without management replacement. He reports that more incomedecreasing discretionary accounting decisions are occurred at the companies with management replacement than the companies without management replacement. Strong and Meyer (1987) study the effect of CEO turnover on reporting decision of CEOs. They find that newly appointed CEOs have a tendency of low earnings reporting at the first year term. Murphy and Zimmerman (1993) also report that newly appointed CEOs in firms of poor performance are more likely to report low earnings at the first CEO term. Pourciau (1993) classifies CEO turnover into routine replacement and non-routine replacement. She reports that managers from non-routine replacement make more 
earnings management decision than CEOs from routine replacement. The result supports the argument that newly appointed CEOs tend to report lower earnings at the first year term. Rhee and Moon (2015) study the newly appointed CEOs' earnings forecasts bias at the first year term. They report that newly appointed CEOs tend to provide more conservative earnings forecasts than optimistic earnings forecasts at the term and explain that new CEOs are able to meet or beat their earnings forecasts easily by providing conservative earnings forecasts. They also argue the tendency of conservative earnings forecasts is reduced as more financial analysts follow the CEOs' companies.

In terms of corporate governance, many researches study that the corporate governance can play a controlling role of managers' earnings management (Xie et al., 2003; Park and Shin, 2002). Xie et al. (2003) report that board members who have working experiences in financial industry help to reduce managers' earnings management. Also, Park and Shin (2002) support the argument that outside directors who have working experience in financial institution can control managers' earnings management.

\section{IFRS Reconciliation}

IFRS reconciliation is the converting process from local GAAP financial statements to IFRS financial statement. Horton and Serafeim (2010) and Christensen et al. (2007) argue that firms' stock price after IFRS adoption can be affected by IFRS reconciliation. Capkun et al. (2008) study European firms with low return on asset (ROA) under local-GAAP and they report that the firms enhance ROA using IFRS reconciliation. However, the phenomenon is appeared when firms are under weak corporate governance. Further, Capkun et al. (2011) investigate the association between the negative earnings reconciliation and managers' opportunistic behavior. They find that a managers' compensation in their company of negative earnings reconciliation is higher than managers' compensation in industry average. It implies that managers use IFRS reconciliation as a mean of maximizing their self-interests. Similarly, Voulgaris et al. (2011) support the argument that managers exploit IFRS reconciliation to increase their self-interests when the managers' compensation is related to their firms' earnings. Garcia-Osma and Pope (2011) report that when the companies yield negative IFRS reconciliation abnormally, the earnings quality of them become worse.

\section{Hypotheses Development}

Korean listed firms are required to adopt IFRS mandatorily in 2011 and they also need to re-prepare IFRS financial statements for 2010 from K-GAAP financial statements for 2010. Therefore, there are two types of financial statements for 2010, IFRS and K-GAAP financial statements, existed from IFRS reconciliation. By comparing two financial statements for 2010, we can figure out the earnings difference between these two financial statements. IFRS, principle based, gives CEOs more discretion about financial reporting and the CEOs can have more capability to manage earnings after IFRS adoption (Donelson et al. 2012). Especially, the purpose of reprepared IFRS financial statements for 2010 is to compare with the financial information for 2011, but the reprepared IFRS financial statements for 2010 do not need to be audited by external auditors. In this circumstance, the CEOs are more likely to apply their discretionary accounting decisions at the process of IFRS reconciliation. In addition, new CEOs have an incentive to report lower earnings at the appointment year for the purpose of big bath (Moore 1973; Strong and Meyer 1987; Pourciau 1993; Rhee and Moon 2015). If CEO turnover is occurred in 2011, newly appointed CEOs who have an incentive of big bath may use IFRS reconciliation in order to reduce IFRS earnings for 2011. Therefore, we predict that the firms with new CEOs will perform negative IFRS reconciliation, reducing the amount of earnings by IFRS reconciliation. Hence, we set the first hypothesis is as follows:

H1: There is a positive association between CEO turnover and negative IFRS reconciliation.

Many IFRS studies report that the effect of IFRS adoption is differently observed by the level of corporate governance (Daske et al. 2008; Li 2010; Christensen et al. 2012). Also, Capkun et al. (2008) argue that corporate governance makes influence to IFRS reconciliation. As the level of corporate governance can affect IFRS reconciliation, the association between CEO turnover and negative IFRS reconciliation may be affected from corporate governance. If a firms' level of corporate governance is strong, the firm managers' opportunistic behaviors are controlled and the managers are less like to use IFRS reconciliation as a tool of big bath. On the other hands, if a 
firms' level of corporate governance is weak, the firm cannot effectively control the managers' opportunistic behaviors and they will use IFRS reconciliation for pursuing their self-interests. Therefore, we predict that the positive association between CEO turnover and negative IFRS reconciliation is disappeared (existed) under strong (weak) corporate governance. Hence, we test whether the level of corporate governance affects the association between CEO turnover and negative IFRS reconciliation in the second hypothesis.

H2: The level of corporate governance affects the association between CEO turnover and negative IFRS reconciliation.

\section{RESEARCH METHODOLOGY}

\section{Definition of CEO and Type of CEO Turnover}

We collect the information of CEO turnover from Data Analysis, Retrieval and Transfer System (DART) of Financial Supervisory Service in Korea. ${ }^{2}$ Generally, many Korean companies have more than one CEO. Therefore, we define CEOs as all directors who have CEO (president) title of their company. For example, the number of CEOs in Kia Motors is varied over the period in Table 1. If the all CEO members are replaced by this year, we consider that CEO turnover is occurred.

Table 1. CEO turnover of Kia Motors

\begin{tabular}{llllll}
\hline \multicolumn{1}{c}{ Periods } & $\sim$ Mar.20.2008 & \multicolumn{1}{c}{$\begin{array}{c}\text { Mar.21.2008 } \\
\text { Mar.5.2009 }\end{array}$} & $\begin{array}{c}\text { Mar.6.2009 } \\
\text { Mar.3.2010 }\end{array}$ & $\begin{array}{c}\text { Mar.4.2010 } \\
\text { Mar.17.2011 }\end{array}$ & Mar.18.2011 \\
\hline \multirow{2}{*}{ Name of CEOs } & $\begin{array}{l}\text { Jung, Mong Gu. } \\
\text { Jung, Euh Sun. } \\
\text { Cho, Nam Hong. }\end{array}$ & $\begin{array}{l}\text { Jung, Mong Gu. } \\
\text { Kim, Ik Hwan. } \\
\text { Cho, Nam Hong. }\end{array}$ & $\begin{array}{l}\text { Jung, Sung Eun. } \\
\text { Seo, Young Jong. }\end{array}$ & Seo, Young Jong. & $\begin{array}{l}\text { Lee, Hyung Keun. } \\
\text { Lee, Sam Wook. }\end{array}$ \\
\hline $\begin{array}{l}\text { Numbers of } \\
\text { CEOs }\end{array}$ & 3 & 3 & 2 & 1 & 2 \\
\hline
\end{tabular}

\section{IFRS Reconciliation and Level of Corporate Governance}

We calculate the amounts of IFRS reconciliation using the information of net income. The adjusted amounts from IFRS reconciliation (IFRS ${ }^{A D J}$ ) is the difference of net income under IFRS for 2010 and net income under KGAAP for 2010 divided by total assets under K-GAAP for 2010. Then, we set that managers have an intention to reduce the earnings using IFRS reconciliation if the adjusted amounts belong to the range of less than $25 \%$ of total firms. Specifically, we construct an indicator variable ( $N_{-} I F R S$; negative IFRS reconciliation) that equals to 1 if the adjust amounts from IFRS reconciliation belong to the range of less than $25 \%$ of total firms, 0 otherwise.

$I F R S^{A D J}=\frac{\text { (Net income under IFRS for } 2010-\text { Net income under } \mathrm{K}-\text { GAAP for 2010) }}{\text { Total assets under K-GAAP for } 2010}$

We measure level of corporate governance of companies using the information given by Korea Corporate Governance Service (KCGS). KCGS evaluates the corporate governance of all listed companies in Korea based on corporate disclosures and the organization provides the corporate governance scores every year. In this study, we use the arithmetic mean of the scores in 2009 and in 2010 to categorize the total sample firms into strong or weak corporate governance. If a firm's score of corporate governance is lesser than the arithmetic mean, we consider that the firm has weak corporate governance. If a firm's score of corporate is greater than the mean, we consider that the firm has strong corporate governance.

\section{Model}

To test our hypothesis 1 and 2 on the association between CEO turnover and negative IFRS reconciliation, we construct two indicator variables; CTO (it equals to 1 if CEO is replaced, 0 otherwise) and $N_{-}$IFRS (it equals to 1

\footnotetext{
${ }^{2}$ DART provides CEO replacement reports. The CEO replacement reports give the $\mathrm{CEO}$ information, number of CEOs, turnover periods, and others. 
if the adjusted amount of IFRS reconciliation belongs to below $25 \%$ of total firms, 0 otherwise). We use negative IFRS reconciliation ( $\left.N \_I F R S\right)$, CEO turnover (CTO), and control variables in the following logit model:

\section{Model 1}

$N_{-} I F R S=\beta_{0}+\beta_{1} C T O+\beta_{2} R O E+\beta_{3} L E V+\beta_{4} S I Z E+\beta_{5} P P E+\beta_{6} I N T+\beta_{7} S E C+\beta_{8} M K T+\beta_{9} B I G 4+\beta_{10} E X C$ $+\beta_{11}$ OWN + INDUSTRY $+e$

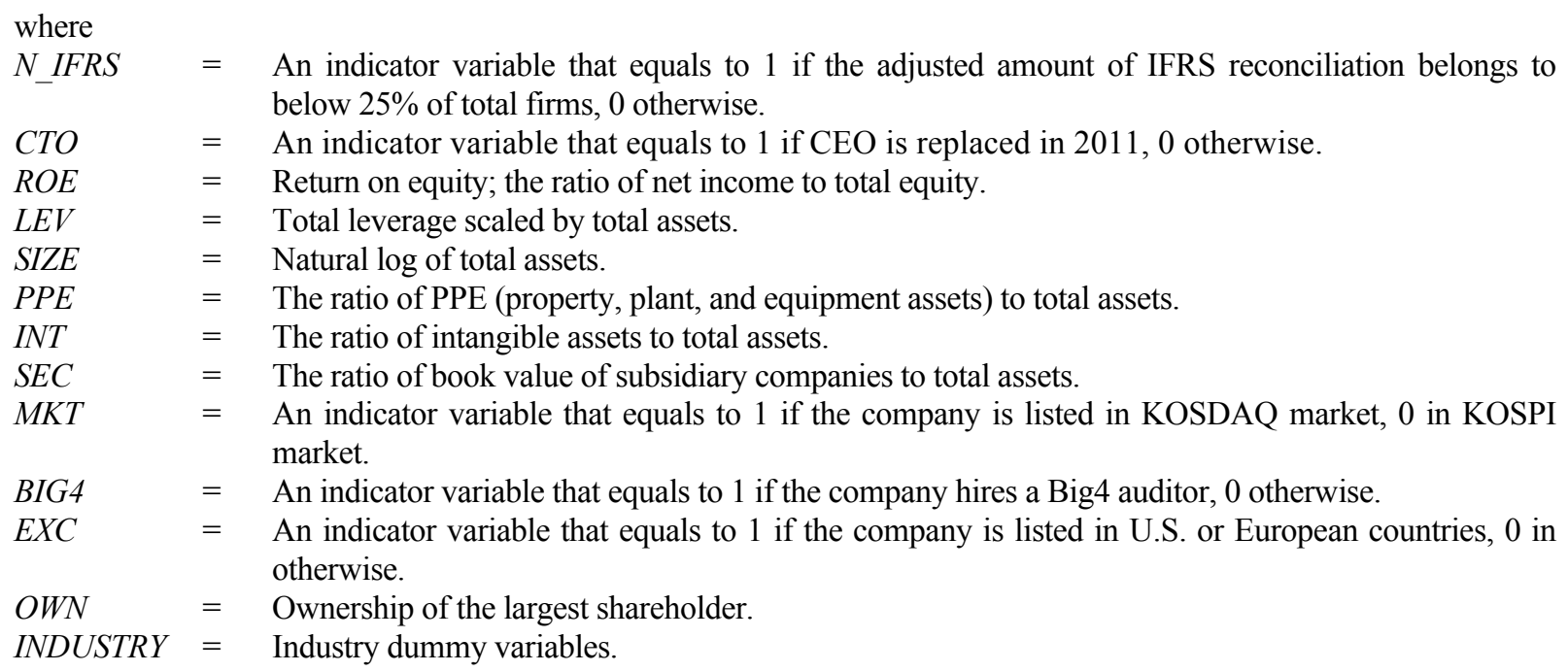

To test our hypothesis 2 , we classify the firms with strong and weak corporate governance and then perform logit analysis respectively. We use control variables which can affect IFRS reconciliation as follows. To control firm size (SIZE) which can affect accounting policy, we take the logarithmic value of total assets (Watts and Zimmerman 1986). Using return on equity $(R O E)$ and leverage ratio $(L E V)$, we control the firms' financial characters which can affect the adjusted amounts from IFRS reconciliation. Basically, IFRS adoption is a switching process of accounting standards and it affects the ratio of assets formation. To control this effect, we add the variable of PPE, INT, and $S E C$. The Korean firms listed in U.S. or European markets are under more complex accounting environment than the firms listed in Korea only, and the firms listed in KOSDAQ market face different accounting environment from the firms listed in KOSPI market. Also, audit quality can affect firms' accounting environment. To control the effect from different accounting environment (Choi, 2013), we set the indicator variables of $E X C, M K T$, and BiG4. Lastly, we add $O W N$ for controlling the effect from largest shareholder.

\section{Sample Selection}

Our empirical tests are based on 684 Korean firm data at the end of the year 2010, which satisfy the following selection criteria: (1) fiscal year ended December 31, (2) firms in non-financial industry, (3) mandatorily IFRS adopted in 2011, (4) the scores of corporate governance are provided from KCGS, and (5) all the control variables are available. We extract IFRS and K-GAAP financial data from Fn-guide and other accounting information from the Korea Information Services Value (Hereafter KisValue) database. All variables are winsorized at top and bottom one-percentile of the pooled data.

\section{EMPIRICAL RESULTS}

\section{Descriptive Statistics}

Table 2 provides descriptive statistics about IFRS reconciliation, CEO turnover, and other variables. The mean of adjusted amount from IFRS reconciliation $\left(I F R S^{A D J}\right)$ and negative IFRS reconciliation $\left(N_{-} I F R S\right)$ are 0.00 and 0.27 respectively. The mean of CEO turnover (CTO) is 0.10 , and the distribution of other control variables is generally consistent with prior studies in Korea. 
Table 2. Descriptive Statistics

\begin{tabular}{l|c|c|c|c|c|c|c|c}
\hline Variables & Mean & Std. Dev. & Min. & $\mathbf{2 5 \%}$ & Med. & $\mathbf{7 5 \%}$ & Max. & N. of obs. \\
\hline$I F R S^{A D J}$ & 0.00 & 0.03 & -0.12 & -0.01 & 0.00 & 0.01 & 0.313 & 684 \\
\hline$N$ IFRS & 0.27 & 0.45 & 0.00 & 0.00 & 0.00 & 1.00 & 1.00 & 684 \\
\hline$C T O$ & 0.10 & 0.31 & 0.00 & 0.00 & 0.00 & 0.00 & 1.00 & 684 \\
\hline$R O E$ & 0.01 & 0.27 & -1.48 & 0.01 & 0.07 & 0.13 & 0.44 & 684 \\
\hline$L E V$ & 0.98 & 0.93 & 0.04 & 0.36 & 0.71 & 1.27 & 5.43 & 684 \\
\hline$S I Z E$ & 25.14 & 1.40 & 22.73 & 24.21 & 24.93 & 25.81 & 29.86 & 684 \\
\hline$P P E$ & 0.27 & 0.18 & 0.00 & 0.13 & 0.26 & 0.39 & 0.73 & 684 \\
\hline$I N T$ & 0.03 & 0.06 & -0.02 & 0.00 & 0.01 & 0.03 & 0.35 & 684 \\
\hline$S E C$ & 0.13 & 0.18 & 0.00 & 0.00 & 0.06 & 0.18 & 0.89 & 684 \\
\hline$M K T$ & 0.6 .3 & 0.48 & 0.00 & 0.00 & 1.00 & 1.00 & 1.00 & 684 \\
\hline$B I G 4$ & 0.54 & 0.50 & 0.00 & 0.00 & 1.00 & 1.00 & 1.00 & 684 \\
\hline$E X C$ & 0.00 & 0.11 & 0.00 & 0.00 & 0.00 & 0.00 & 1.00 & 684 \\
\hline$O W N$ & 0.40 & 0.17 & 0.07 & 0.28 & 0.39 & 0.52 & 0.79 & 684 \\
\hline
\end{tabular}

Univariate Analysis.

Table 3 presents the Pearson correlations among negative IFRS reconciliation ( $N_{-}$IFRS), CEO turnover (CTO), and other variables. In this table, $N$ IFRS is positively correlated with CTO, and it implies that newly appointed CEOs tend to perform negative IFRS reconciliation. However, the association is insignificant. As the implication of the univariate result appears to be limited, we perform the multivariate logit analyses to examine the overall association between negative IFRS reconciliation $\left(N_{-}\right.$IFRS ) and CEO turnover $(C T O)$ coupled with control variables. Most control variables are correlated each other as expected.

Table 3. Univariate Correlation among the Main Variables

\begin{tabular}{|c|c|c|c|c|c|c|c|c|c|c|c|}
\hline Var. & N_IFRS & CTO & $R O E$ & LEV & SIZE & $P P E$ & $I N T$ & SEC & MKT & BIG4 & $E X C$ \\
\hline СTO & $\begin{array}{c}0.048 \\
(0.20)\end{array}$ & & & & & & & & & & \\
\hline ROE & $\begin{array}{r}0.075 \\
(0.04) \\
\end{array}$ & $\begin{array}{c}-0.194 \\
(0.00)\end{array}$ & & & & & & & & & \\
\hline$L E V$ & $\begin{array}{l}-0.065 \\
(0.08)\end{array}$ & $\begin{array}{c}0.126 \\
(0.00) \\
\end{array}$ & $\begin{array}{c}-0.305 \\
(0.00)\end{array}$ & & & & & & & & \\
\hline SIZE & $\begin{array}{c}0.108 \\
(0.00)\end{array}$ & $\begin{array}{l}-0.014 \\
(0.70) \\
\end{array}$ & $\begin{array}{c}0.258 \\
(0.00)\end{array}$ & $\begin{array}{l}-0.106 \\
(0.66)\end{array}$ & & & & & & & \\
\hline PPE & $\begin{array}{l}-0.129 \\
(0.00) \\
\end{array}$ & $\begin{array}{l}-0.010 \\
(0.79) \\
\end{array}$ & $\begin{array}{l}0.001 \\
(0.96) \\
\end{array}$ & $\begin{array}{c}0.184 \\
(0.00) \\
\end{array}$ & $\begin{array}{l}-0.026 \\
(0.48) \\
\end{array}$ & & & & & & \\
\hline$I N T$ & $\begin{array}{l}-0.061 \\
(0.11) \\
\end{array}$ & $\begin{array}{l}-0.026 \\
(0.48) \\
\end{array}$ & $\begin{array}{l}-0.175 \\
(0.00) \\
\end{array}$ & $\begin{array}{l}-0.085 \\
(0.02) \\
\end{array}$ & $\begin{array}{c}-0.016 \\
(0.66) \\
\end{array}$ & $\begin{array}{c}-0.198 \\
(0.00) \\
\end{array}$ & & & & & \\
\hline$S E C$ & $\begin{array}{c}0368 \\
(0.00) \\
\end{array}$ & $\begin{array}{l}-0.001 \\
(0.96) \\
\end{array}$ & $\begin{array}{c}0.022 \\
(0.55) \\
\end{array}$ & $\begin{array}{l}-0.3164 \\
(0.00) \\
\end{array}$ & $\begin{array}{r}0.175 \\
(0.00) \\
\end{array}$ & $\begin{array}{l}-0.367 \\
(0.00) \\
\end{array}$ & $\begin{array}{l}-0.147 \\
(0.00) \\
\end{array}$ & & & & \\
\hline$M K T$ & $\begin{array}{l}-0.105 \\
(0.00)\end{array}$ & $\begin{array}{l}-0.043 \\
(0.25)\end{array}$ & $\begin{array}{l}-0.084 \\
(0.02)\end{array}$ & $\begin{array}{l}-0.075 \\
(0.04)\end{array}$ & $\begin{array}{l}-0.343 \\
(0.00)\end{array}$ & $\begin{array}{l}-0.075 \\
(0.04) \\
\end{array}$ & $\begin{array}{l}01.204 \\
(0.00)\end{array}$ & $\begin{array}{l}-0.157 \\
(0.00)\end{array}$ & & & \\
\hline BIG4 & $\begin{array}{r}0.048 \\
(0.20) \\
\end{array}$ & $\begin{array}{r}0.009 \\
(0.80)\end{array}$ & $\begin{array}{r}0.163 \\
(0.00) \\
\end{array}$ & $\begin{array}{c}0.026 \\
(0.49)\end{array}$ & $\begin{array}{c}0.392 \\
(0.00) \\
\end{array}$ & $\begin{array}{r}0.005 \\
(0.87)\end{array}$ & $\begin{array}{l}-0.084 \\
(0.02)\end{array}$ & $\begin{array}{c}0.084 \\
(0.02) \\
\end{array}$ & $\begin{array}{l}-0.254 \\
(0.00)\end{array}$ & & \\
\hline$E X C$ & $\begin{array}{r}0.043 \\
(0.25) \\
\end{array}$ & $\begin{array}{c}0.002 \\
(0.94) \\
\end{array}$ & $\begin{array}{r}0.055 \\
(0.14) \\
\end{array}$ & $\begin{array}{l}-0.011 \\
(0.75) \\
\end{array}$ & $\begin{array}{r}0.327 \\
(0.00) \\
\end{array}$ & $\begin{array}{r}0.041 \\
(0.27) \\
\end{array}$ & $\begin{array}{c}0.047 \\
(021) \\
\end{array}$ & $\begin{array}{l}-0.001 \\
(096) \\
\end{array}$ & $\begin{array}{l}-0.122 \\
(0.00) \\
\end{array}$ & $\begin{array}{r}0.107 \\
(0.00) \\
\end{array}$ & \\
\hline$O W N$ & $\begin{array}{r}0.065 \\
(0.08) \\
\end{array}$ & $\begin{array}{l}-0.034 \\
(0.37) \\
\end{array}$ & $\begin{array}{r}0.145 \\
(0.00) \\
\end{array}$ & $\begin{array}{c}0.026 \\
(0.49) \\
\end{array}$ & $\begin{array}{c}0.002 \\
(0.93) \\
\end{array}$ & $\begin{array}{c}0.088 \\
(0.02) \\
\end{array}$ & $\begin{array}{l}-0.206 \\
(0.00) \\
\end{array}$ & $\begin{array}{r}0.117 \\
(0.00) \\
\end{array}$ & $\begin{array}{l}-0.134 \\
(0.00) \\
\end{array}$ & $\begin{array}{c}0.092 \\
(0.01) \\
\end{array}$ & $\begin{array}{l}-0.079 \\
(0.03) \\
\end{array}$ \\
\hline
\end{tabular}

\section{Multivariate Analysis}

Table 4 presents the results from a multivariate logit analysis for investigating the effect of CEO replacement on negative IFRS reconciliation. In Table 4, CEO turnover (CTO) is positively associated with negative IFRS reconciliation $\left(N_{-} I F R S\right)$ at five percent or less of significance level $(\mathrm{t}$-stat=2.05). This positive association suggests that newly appointed CEO are likely to report negative IFRS reconciliation at the point of CEO turnover year, supporting the hypothesis 1. ROE and SEC are also positively correlated with $N_{-}$IFRS in Table 4. As a firm' 
return on equity or the ratio of book value of subsidiary companies to total assets increases, the firm tends to reduce earnings using IFRS reconciliation.

Next, we classify the companies into strong and weak corporate governance in order to examine whether new CEOs' opportunistic behavior of negative IFRS reconciliation is still existed under strong and weak corporate governance. Table 5 presents the association between CEO turnover (CTO) and negative IFRS reconciliation $\left(N_{-} I F R S\right)$ under strong and weak corporate governance. In the first column in Table 5 which is a multivariate result of the group of strong corporate governance, the coefficient of $C T O$ is insignificantly positive $(t-s t a t=0.56)$ and we do not find strong evidence that newly appointed CEOs are likely to use IFRS reconciliation for reporting lower IFRS earnings under strong corporate governance. On the other hand, in the second column of Table 5 which is a multivariate result of the group of weak corporate governance, we find very significant evidence that newly appointed CEOs tend to perform negative IFRS reconciliation under weak corporate governance $(t-s t a t=2.74)$. Taken together, the overall results in Table 5 indicate that the opportunistic behavior of negative IFRS reconciliation from new CEOs is observed generally in firms with weak corporate governance, whereas the opportunistic behavior is controlled in firms with strong corporate governance. It also supports the prior IFRS studies' arguments that IFRS adoption takes effect differently by the level of corporate governance.

Table 4. Results of Multivariate Logit Analysis

$N_{I} I F R S=\beta_{0}+\beta_{1} C T O+\beta_{2} R O E+\beta_{3} L E V+\beta_{4} S I Z E+\beta_{5} P P E+\beta_{6} I N T+\beta_{7} S E C+\beta_{8} M K T+\beta_{9} B I G 4+\beta_{10} E X C+\beta_{11} O W N+$ INDUSTRY $+e$

\begin{tabular}{|c|c|c|}
\hline \multirow{2}{*}{ Independent Variable } & \multicolumn{2}{|c|}{ N_IFRS } \\
\hline & Estimate & z-stat \\
\hline Intercept & -1.9467 & -0.83 \\
\hline CTO & $0.6394 * *$ & 2.05 \\
\hline$R O E$ & $0.8799 *$ & 1.75 \\
\hline$L E V$ & -0.0435 & -0.34 \\
\hline SIZE & 0.0375 & 0.43 \\
\hline$P P E$ & -0.2244 & -0.30 \\
\hline$I N T$ & 0.6852 & 0.32 \\
\hline SEC & $4.4927 * * *$ & 6.12 \\
\hline$M K T$ & -0.1032 & -0.43 \\
\hline$B I G 4$ & -0.0425 & -0.19 \\
\hline$E X C$ & 0.5175 & 0.61 \\
\hline$O W N$ & -0.3103 & -0.48 \\
\hline Industry & & \\
\hline Model $X^{2}$ & & \\
\hline \# of Samples & & \\
\hline
\end{tabular}

Note: $\mathrm{t}$-statistics are reported in bracket. $* * *, * *, *$ indicate, respectively, the significance level at the $1 \%, 5 \%$ and $10 \%$ level or better. See [Model 1] for the definitions of the variables. 
Table 5. Results of Multivariate Logit Analysis (Level of corporate governance)

$N_{I} I F R S=\beta_{0}+\beta_{1} C T O+\beta_{2} R O E+\beta_{3} L E V+\beta_{4} S I Z E+\beta_{5} P P E+\beta_{6} I N T+\beta_{7} S E C+\beta_{8} M K T+\beta_{9} B I G 4+\beta_{10} E X C+\beta_{11} O W N+$ INDUSTRY $+e$

\begin{tabular}{|c|c|c|c|c|}
\hline \multirow{3}{*}{ Independent Variable } & \multicolumn{4}{|c|}{ N_IFRS } \\
\hline & \multicolumn{2}{|c|}{ Strong corporate governance } & \multicolumn{2}{|c|}{ Weak corporate governance } \\
\hline & Coef. & z-stat & Coef. & z-stat \\
\hline Intercept & -2.2614 & -0.60 & -1.2850 & -0.33 \\
\hline CTO & 0.2978 & 0.56 & $1.2170^{* * *}$ & 2.74 \\
\hline$R O E$ & 1.7608 & 1.19 & $1.0390 *$ & 1.83 \\
\hline$L E V$ & -0.1062 & -0.49 & -0.0525 & -0.289 \\
\hline SIZE & 0.0042 & 0.03 & 0.0330 & 0.22 \\
\hline$P P E$ & -0.3417 & -0.27 & 0.1365 & 0.13 \\
\hline$I N T$ & 0.2916 & 0.05 & -0.2970 & -0.12 \\
\hline SEC & $6.669288 * * *$ & 5.22 & $3.3208^{* * *}$ & 3.22 \\
\hline$M K T$ & -0.2680 & -0.70 & 0.1181 & 0.31 \\
\hline$B I G 4$ & 0.0082 & 0.02 & -0.1710 & -0.55 \\
\hline$E X C$ & 1.3922 & 1.34 & & \\
\hline$O W N$ & -0.7592 & -0.70 & -0.4338 & 0.47 \\
\hline Industry & \multirow{3}{*}{\multicolumn{2}{|c|}{$\begin{array}{c}\text { Included } \\
99.67(\mathrm{p}<0.00) \\
333\end{array}$}} & \multirow{3}{*}{\multicolumn{2}{|c|}{$\begin{array}{c}\text { Included } \\
63.43(\mathrm{p}<0.00) \\
351\end{array}$}} \\
\hline Model X ${ }^{2}$ & & & & \\
\hline \# of Samples & & & & \\
\hline
\end{tabular}

Note: t-statistics are reported in bracket. $* * *, * *, *$ indicate, respectively, the significance level at the $1 \%, 5 \%$ and $10 \%$ level or better. See [Model 1] for the definitions of the variables.

\section{CONCLUSION}

Basically, newly appointed CEOs have an incentive to reduce their firms' earnings at the first CEO year, and then they can report incremental future earnings smoothly during their overall terms. In this study, we examine whether the new CEOs use IFRS reconciliation as a mean of big bath and prepare negative IFRS reconciliation. Using 684 Korean listed firm data, we find that there is a significantly positive association between CEO turnover and negative IFRS reconciliation. We interpret this result that newly appointed CEOs are more likely to use IFRS reconciliation opportunistically for report lower earnings. Furthermore, we categorize the firms as the group of strong corporate governance and the group of weak corporate governance for testing the effect of corporate governance to the association between CEO turnover and IFRS reconciliation. From our empirical analysis, we find that new CEOs' opportunistic behavior of negative IFRS reconciliation is disappeared (existed) in the companies with strong (weak) corporate governance.

Nonetheless, we acknowledge that our findings may have following caveats. First, there may be other omitted factors which bias our empirical results. In addition, we cannot rule out the possibility that our results largely depend on measurement criteria. Second, we could not distinguish the voluntariness of CEO turnover due to data limitation in this study. Whether preceding CEOs are replaced voluntarily or non-voluntarily may be an important factor because it is related to firm situation and CEO's capability. We view the exploration about the effect of voluntariness of CEO turnover on IFRS reconciliation as a rich avenue for further research.

Despite these caveats, we believe that our study will contribute to academics and disclosure-related practitioners by providing valuable information of the CEO incentive regarding IFRS reconciliation. Also, this study provides insight into the importance of corporate governance on the relation between new CEO appointment and IFRS reconciliation. Lastly, we believe that our empirical evidence will be helpful to market participants when they make an important business decisions in case of CEO turnover.

\section{AUTHOR INFORMATION}

Eun Sil Choi ( $1^{\text {st }}$ Author) earned Ph.D. degree at Korea University in Korea. Research interests include International Financial Reporting Standards, and value relevance of accounting information. Email: es2011@korea.ac.kr 
Chang Seop Rhee (corresponding author) is an assistant professor of School of Business at Sejong University in

Korea. Research interests include International Financial Reporting Standards, equity valuation, management earnings forecasts, and other financial \& managerial accounting issues. Email: crhee2@sejong.ac.kr

\section{REFERENCES}

Capkun, V., A. C. Jeny, T. Jeanjean, \& L. A. Weiss. (2008). Earnings management and value relevance during the mandatory transition from local GAAPs to IFRS in Europe. Working paper, HEC Paris.

Capkun, V., D. W. Collins, \& T. Jeanjean. (2011). Does adoption of IAS/IFRS deter earnings management?. Working paper, HEC Paris.

Choi, E. S. (2013). IFRS adoption and cost of equity capital: Korean evidence. Working paper.

Christensen, H. B., Lee, E., \& Walker, M. (2007). Cross-sectional variation in the economic consequences of international accounting harmonization: The case of mandatory adoption in the UK. The International Journal of Accounting, 42 (4), 341-379.

Christensen, H. B., Hail, L., \& Leuz, C. (2012). Mandatory IFRS reporting and changes in enforcement. Working paper.

Daske, H., L. Hail, C. Leuz, \& R. Verdi. (2008). Mandatory IFRS reporting around the world: Early evidence on the economic consequences. Journal of Accounting Research, 46(5), 1085-142.

Donelson, D. C., J. McInnis, \& R. D. Mergenthaler. (2012). Rules-Based accounting standards and litigation. The Accounting Review, 87(4), 1247-1279.

Horton, J., \& G. Serafeim. (2010). Market reaction to and valuation of IFRS reconciliation adjustments: first evidence from the UK. Review of Accounting Studies, 15(4), 725-751.

Garcia Osma, B., \& P. F. Pope. (2011). Strategic balance sheet adjustments under first-time IFRS adoption and the consequences for earnings quality. Working paper.

Li, S. (2010). Does mandatory adoption of international financial reporting standards in the European Union reduce the cost of equity capital? The Accounting Review, (March), 607-636.

Moore, M. (1973). Management change and discretionary accounting decisions. Journal of Accounting Research, 11(1), 100-107.

Murphy, K. J., \& J. Zimmerman. (1993). Financial performance and surrounding CEO turnover. Journal of Accounting and Economics, 16(1-3), 273-315.

Park, Y. W., \& H. Shin. (2004). Board composition and earnings management in Canada. Journal of Corporate Finance, 10(3), 431-27.

Pourciau, S. (1993). Earnings management and nonroutine executive changes. Journal of Accounting and Economics, 16(1-3), 317-336.

Rhee, C. S., \& B. Moon. (2015). New chief executive officers' earnings forecasts bias at their first year term and role of financial analysts: Korean evidence. Journal of Applied Business Research, 31(4), Forthcoming.

Strong, J. S., \& J. R. Meyer. (1987). Asset writedowns: managerial incentives and security returns. Journal of Finance, 42(3), 643-661.

Voulgaris, G., K. Stathopoulos, \& M. Walker. (2011). IFRS and the use of accounting-based performance measures in executive pay. Working paper.

Watts, R., \& J. Zimmerman. (1986). Positive Accounting Theory. Englewood Cliffs, NJ: Prentice-Hall.

Xie, B., W. N. Davidson, \& P. J. DaDalt. (2003). Earnings management and corporate governance: the role of the board and the audit committee. Journal of Corporate Finance, 295-316. 


\section{NOTES}

